\title{
RESPONSE OF CASSAVA PLANT TO WATER REQUIREMENTS AND THE LEVELS OF ORGANIC MANURE. El-Shal, Z. S. ${ }^{1}$ and Soad M. El-Ashry ${ }^{2}$ \\ ${ }^{1-}$ Vegetables Res. Dept. Hort. Res. Inst., Agri. Res. Center, Cairo Egypt. \\ ${ }^{2}$-Soils and water use, National Res. Center, Dokki, Cairo, Egypt.
}

\section{ABSTRACT}

Two field experiments were carried out during the two successive seasons of 2009 and 2010 at south El-Tahrir Research Station, (Ali Moubarak) Horticulture Research Institute to study the response of cassava plants to the combination between three rates of water requirements and compost manure at three rates of application. Obtained results were as follows:

1- The longest plants, highest leaves and largest length and diameter of branches as well as the heaviest total cassava yield and its best physical (tuber length and diameter) and chemical characters expresed as N,P and K contents of tuber tissues were recorded with cassava plants received 35 ton/fed. of compost followed in descending order by the addition of compost manure at 30 ton/fed. and the finally the application of 25 ton/fed. of compost manure.

2- The medium and high level of irrigation water (100 and 120\%) encouraged the vegetative growth of cassava plants expresed as number of leaves, stem length, number of later branches and branches diameter and total tuber yield and the highest values of physical and chemical tuber quality i.e. tuber length and diameter as well as N,P and K contents of tuber tissues.

3- In spite of the non significant effect of the interaction of water requirements and the levels of compost manure application in the two seasons.

\section{INTRODUCTION}

Cassava is one of the most important staple foods in the human diet in the tropics and ranked as the sixth most important source of calories in the human diet worldwide (FAO 1996 and Alfredo et al., 2000). Cassava leaves and tender shoots are consumed, because the leaves contain about $7 \%$ of protein and high level of lysine Mabrouk et al. (1987). Cassava is a competitive crop, espicially for the production of starch, animal feed and alcohol production (Fuglie 2002 and Oguntunde 2005). Cassava is well known as a resistant crop, especially to climate and soil conditions. It cangrow in places where cereals and other crops do not grow well. It can tolerate drought and can grow in low nutrient soil.

Water is a major constituent of living plant tissues, which consists of about $90 \%$ water. Whereas, all biological processes within the living plants depend on it. Further, the optimal moisture conditions for any crop vary depending on many factors such as soil type, climate conditions, growth rate and habit .....etc. The favourable soil moisture tension should be maintained throughout the entire growth period of plants due to the relationship between evapotranspiration and biomass production Singh and Alderfer (1966). Moreover, non stable irrigation schedule widely affected vegetative growth, yield and crop quality Singh, ( 1989). On the other hand, Egytion water resources are limited, so it is advised to evaluate new possible approaches to minmize the plant water consumption and hence to rationalize irrigation water 
use. Many investigation were carried out to determine the best irrigation regime for cassava plants. Some of them reported that irrigation regimens influenced tuber yield and the highest tuber yield was registered for $30 \%$ irrigation regimen Erdem et al (2006). On the same respect, Hair and Lameberts (1995) and El-Khatib et al (2007) found that evaluate irrigation water requirements and determine an irrigation schedule for cassava crop. Two quantities of applied irrigation water ( $100 \%$ of the ET and $80 \%$ of the ET). The results indicated that, yield components of cassava, i.e. was increased the total number of tubers per plant, the average length and diameter of tubers and the weight of fresh tubers/ plant when used two days interval irrigation associated with 100\% ET. Moreover, Ghuman (2003), Amanullah et al (2006), Olanrewaju et al (2009) and Obafemi et al (2011) indicated that $100 \%$ availabe water produced the higest stem diameter, average leaf number, mean tuber yield and tuber quality on cassava plants.

Soil fertility maintenance is very essential in achieving and maintaining high crop yields over a period of time. There is the need to apply fertilizers to maintain soil fertility. Nutrients contained in organic manures are released more slowly and are stored for a longer time in the soil, thereby ensuring a long residual effect Sharme and Mittra (1991). Supporting better root development, leading to higher crop yields AbouEl-Magd et al (2005). Improvement of environmental conditions as wellas need to reduce costs of fertilizing crops are also important reasons for advocating increased use of organic materials Bayu et al (2006). They improve the soil fertility status by activating the soil microbial biomass Ayuso et al (1996). They are required in rather large quantities to meet up with crops nutrient supply. Application of organic manures sustains cropping system through better nutrient recycling El-Shakweer et al (1998). They play a direct role in plant growth as a source of all necessary macro and micronutrients in available forms during mineralization, thereby improving both the physical and the biological properties of the soil AbouEl-Magd et al (2006). Organic manure decompose to give humus which plays an important role in the chemical behaviour of several metals in soils through the flavonic and humic acid contents, which have the ability to retain the metal in complex and chelate forms. Organic manures also improve the water holding capacity of the soil, improve the soil structure, the soil aeration and a positive influence on the growth, yield and the best results of cassava tubers (Belay et al 2001. Amanullah et al 2006 and Makinde and Ayoola 2008). However, high and sustained crop yield could be obtained with balanced NPK fertilization combined with organic matter amendments Bayu et al (2006). On the other hand, Ayoola and Makinde (2007) indicated that, sole organic fertilizer had a significantly lower cassava root yield in the first year of experiment bot, the second year however, yields under the various fertilizer treatments were statistically similar.

This investigation aimed to investigate the effect of varios combination of levels of compost manure ( $0,25,30$ and $35 \mathrm{t} / \mathrm{fed}$.) with water use effeciency to limited irrigation water supply (from $80 \%, 100 \%$ and $120 \%$ of ET) on the growth, yield and tuber quality of cassava under sandy soil conditions. 


\section{MATERIALS AND METHODS}

The present study was performed under sandy soil conditions at south El-Tahrir Research Station, (Ali Moubarak) Horticulture Research Institute, during the two successive seasons, 2009 and 2010. Cassava stem cuttings of Indonesian cultivar and were planted on 24 / 3 /2009 and 10 /4 /2010 in the two seasons. A drip irrigation system was adapted for irrigation.

Soil analysis was carried out according to Wiled et al (1985); the obtained data are shown in Table (1 and 2). And Table (3) shows the chemical analysis of the compost manure, which used in this study.

Table (1): Physical properties of the experimental soil.

\begin{tabular}{|l|c|c|c|c|c|c|c|}
\hline $\begin{array}{c}\text { Depth } \\
\text { (cm) }\end{array}$ & \multicolumn{2}{|c|}{ Particle size distribution \% } & \multirow{2}{*}{ F.C.$\%$} & W.P &.$\%$ & $\begin{array}{c}\text { Texture } \\
\text { class }\end{array}$ \\
\cline { 2 - 8 } & sand & Fine sand & silt & clay & & 4.3 & sandy \\
\hline $0-30$ & 52.00 & 40.27 & 4.40 & 3.33 & 9.4 & 4.3 & sandy \\
\hline $30-60$ & 48.00 & 42.53 & 4.80 & 4.67 & 8.5 & 4.4 & sand \\
\hline
\end{tabular}

Table (2): some chemical properties of the experimental soil.

\begin{tabular}{|c|c|c|c|c|c|c|c|c|c|}
\hline \multirow{2}{*}{$\begin{array}{c}\text { Depth } \\
\text { (cm) }\end{array}$} & \multirow{2}{*}{ pH } & \multirow{2}{*}{$\begin{array}{c}\text { Ec } \\
\mathrm{ds} / \mathrm{m}\end{array}$} & \multicolumn{4}{|c|}{ Soluble actions $\mathrm{meg} / \mathrm{I}$} & \multicolumn{3}{|c|}{ Soluble anions $\mathrm{meg} / \mathrm{I}$} \\
\hline & & & $\mathrm{Ca}^{++}$ & $\mathbf{M g}^{++}$ & $\mathrm{Na}^{+}$ & $\mathrm{K}^{+}$ & $\mathrm{HCO}_{3}$ & $\mathrm{So}_{4}$ & $\mathrm{Cl}$ \\
\hline $0-30$ & 7.83 & 1.49 & 5.75 & 4.60 & 3.60 & 0.2 & 4.60 & 2.75 & 6.80 \\
\hline $30-60$ & 7.91 & 1.27 & 5.75 & 4.20 & 3.40 & 0.3 & 4.70 & 2.80 & 6.90 \\
\hline
\end{tabular}

Table (3): The chemical analysis of the used compost manure.

\begin{tabular}{|l|c|}
\hline \multicolumn{1}{|c|}{ characters } & Plant compost manure \\
\hline $\mathrm{Ph}$ & 8.55 \\
\hline Ec & 6.05 \\
\hline Organic carbon\% & 30.2 \\
\hline Total nitrogen\% & 1.76 \\
\hline C/N ratio & $17.2 / 1$ \\
\hline Total phosphorus\% & 1.30 \\
\hline Total potassium\% & 1.28 \\
\hline Fe mg/ kg & 7900 \\
\hline Mn mg / kg & 190 \\
\hline Copper mg / kg & 20 \\
\hline Zink mg/ kg & 4.75 \\
\hline
\end{tabular}

The experimental treatments can be illustrated as follows:

$1-80 \%$ irrigation +0 (ton/fed.) compost.

$2-80 \%$ irrigation +25 (ton/fed.) compost.

3- $80 \%$ irrigation +30 (ton/fed.) compost.

$4-80 \%$ irrigation +35 (ton/fed.) compost.

$5-100 \%$ irrigation +0 (ton/fed.) compost.

$6-100 \%$ irrigation +25 (ton/fed.) compost.

$7-100 \%$ irrigation +30 (ton/fed.) compost.

8- $100 \%$ irrigation +35 (ton/fed.) compost.

$9-120 \%$ irrigation +0 (ton/fed.) compost.

10- $120 \%$ irrigation +25 (ton/fed.) compost.

$11-120 \%$ irrigation +30 (ton/fed.) compost.

12- $120 \%$ irrigation +35 (ton/fed.) compost. 
The experimental desion was split plot with three replicates, the irrigation levels occupied the main plots and the level of compost manure treatments were dustributed in the sub-plots. The experimental plot area was $\left(8.33 \mathrm{~m}^{2}\right)$ consisted of 1 rows, $1 \mathrm{~m}$ width and $8.33 \mathrm{~m}$ length for each one. All other agricultural practices for cassava plant were carried out according to the recommendation of Egytion Ministry of Agriculture. Calculation of potential evaporanspiration (ET) was made according to the original method of Penman (1948) and the amount of irrigation water was calculated according to Doormbos and Pruitt (1977).

\section{Recorded data:}

A- Vegetative growth:

Three plants of each plot were chosen randomly at 180 days after planting in order to determine the vegetative growth parameters, i.e., number of leaves, number of main branches, main branches diameter, height of branches, branches diameter, number of later branches as well as the laterel branches diameter.

\section{B- Total yield of tubers:}

At harvestting time at 180 days after planting the yield traits, i.e., yield of tuber/ plant and per fed., average weight of tuber $\mathrm{kg}$ and number of tubers per plant were measured.

\section{C- Tuber quality:}

Six plants within each treatment at 180 days after planting as samples for determining the tuber length and diameter and nitrogen, phosphorus and potassium concentrations of tubers according to the methods of Black (1965) for N\%, Trough and Meyer (1939) for P\%, Brown and Lilleland (1958) for K\% and Dubais et al (1951) for Carbohydrate.

\section{D- Statistical analysis:}

Obtained data were subjected to statistical analysis of variances of the split plot design according to the procedure outlined by Gomez and Gomez (1984).

\section{RESULTS AND DISCUSSION}

\section{Growth characters:}

\section{a) Effect of irrigation water requirements:}

The effect of irrigation water requirements on growth characters of cassava plant is presented in Table (4). It is clear that irrigation with water requirements at $100 \%$ and $120 \%$ increased number of leaves, stem length, number of later branches and branches diameter compared with those received $80 \%$ of the water requirements. These findings were true in both experimental seasons. On the other hand, number of branches in the second season and stem diameter in the first season it was not significant. The improvement of cassava plants vegetative growth with increasing irrigation water requirements may be due to the proper balance of moisture in plant, which creates favorable conditions for nutrients uptake, photosynthesis and metabolites translocation, which ultimately accelerated the rate of vegetative growth Ghuman (2003), Amanullah et al (2006), El-Khatib et al (2007), Olanrewaju et al (2009) and Obafemi et al (2011) came to similar results. 
J. Plant Production, Mansoura Univ., Vol. 3 (7), July, 2012

4

2215 


\section{Effect of compos levels:}

The compost treatments significantly increased all the previous mentioned growth parameters compared to that without compost. Results demonstrated clearly that using compost had a positive effect on the aforementioned growth characters of cassava plants which were significantly increased by the different levels of compost fertilization (Table 4). Composting application at a level of $35 \mathrm{ton} / \mathrm{fed}$. gave the highest values of number of leaves, stem length, number of later branches and branches diameter followed by 0 and 25 ton compost / fed. In the two studied seasons, except those of stem diameter in the first season it was not significant. However, the differences between 30 and 35 ton compost / fed. were not significant in both seasons. Obtained results suggest that the best vegetative cassava plant growth could be gained under this investigation within 30 to 35 ton compost/ fed. it might be concluded that addition of compos manure to the cassava plant caused an increase of the nutritional elements in rooting zone, consequently the more nutrients were absorbed so more and enhancement of growth plant. and also due to increased availability of nutrients especially $\mathrm{N}, \mathrm{P}, \mathrm{K}, \mathrm{Zn}, \mathrm{Fe}$ and $\mathrm{Mn}$ even from the early stage of crop growth. Many investigations studied the behavior of many vegetable crops to the addition of organic compost manure fertilization and obtained a data supported that mentioned here (Belay et al 2001, Amanullah et al 2006 and Makinde and Ayoola 2008).

\section{Effect of the interaction:}

The interaction effect of irrigation water quantity with compost levels. On the cassava plant growth characters Table (4) recorded a significant value in both seasons except number of branches, branches diameter and number of later branches in both season and stem length and stem diameter in second season. Generally, in spite of the non-significant response of the above characters the best plant growth, i.e., the longest plants, highest leaves and largest length and diameter of branches were recorded with that cassava plants which received 35 ton/fed. of compost with $100 \%$ irrigation water quantity. On the contrary, the poorest cassava plant growth was associated with that plants received the lowest rate of compost manure 0 ton/fed. of compost with $80 \%$ irrigation water quantity. These results were consequently similar in both experimental seasons.

\section{Total tuber yield:}

\section{Effect of irrigation water quantity:}

Data in Tables (5) showed that the lowest values of total yield of tuber per plant and per ton/fed. as well as, average weight of tuber were recorded with the plants which received low water requirements $(80 \%$ of the calculated water requirements). On the other hand, the highest total tuber yield per plant, total tuber yields per fed. and average tuber weight were achieved when cassava plants were irrigated by $120 \%$ of the calculated water requirements. Obtained results showed the same trend in both growing seasons. The high level of irrigation water requirements (120\%) encouraged the vegetative growth of cassava plants as shown in Table (3) this in turn reflected its effect on total yield of tuber and tuber quality ( average tuber weight). These results are in agreement with those found by Hair and 
Lameberts (1995) and El-Khatib et al (2007) they found that, yield was more negatively affected by high water supply and the tuber quality was the best with continuous water supply. Also, our results are in agreement with Olanrewaju et al (2009) and Obafemi et al (2011). Data also cleared that there were insignificant between the two levels $100 \%$ and $120 \%$ of water requirements.

Table (5): Effect of water requirements and compost manure application on total yield of cassava plants during two experimental seasons.

\begin{tabular}{|c|c|c|c|c|c|c|c|c|c|}
\hline \multirow[t]{2}{*}{ Irrigation } & \multirow[t]{2}{*}{$\begin{array}{l}\text { Compost } \\
\text { (ton/fed.) }\end{array}$} & $\begin{array}{c}\text { Yield } \\
\text { of } \\
\text { tuber } \\
\text { /plant } \\
\text { kg }\end{array}$ & $\begin{array}{c}\text { Yield } \\
\text { (ton/fed.) }\end{array}$ & $\begin{array}{c}\text { Average } \\
\text { wt. of } \\
\text { tuber } \\
(\mathbf{k g})\end{array}$ & $\begin{array}{l}\text { No. of } \\
\text { tuber } \\
\text { /plant }\end{array}$ & \begin{tabular}{|c|}
$\begin{array}{c}\text { Yield } \\
\text { of } \\
\text { tuber } \\
\text { /plant } \\
\text { kg }\end{array}$ \\
\end{tabular} & $\begin{array}{c}\text { Yield } \\
\text { (ton/fed.) }\end{array}$ & $\begin{array}{c}\text { Average } \\
\text { wt. of } \\
\text { tuber } \\
(\mathbf{k g})\end{array}$ & $\begin{array}{l}\text { No. of } \\
\text { tuber } \\
\text { /plant }\end{array}$ \\
\hline & & \multicolumn{4}{|c|}{$2009 / 2010$} & \multicolumn{4}{|c|}{$2010 / 2011$} \\
\hline \multirow{4}{*}{$80 \%$} & 0 & 1.986 & 7.94 & 0.633 & 3.16 & 1.992 & 7.97 & 0.617 & 2.94 \\
\hline & 25 & 1.952 & 7.81 & 0.671 & 3.31 & 1.904 & 7.62 & 0.671 & 2.84 \\
\hline & 30 & 2.390 & 9.56 & 0.673 & 3.31 & 2.313 & 9.25 & 0.686 & 3.16 \\
\hline & 35 & 2.540 & 10.16 & 0.702 & 3.27 & 2.621 & 10.49 & 0.699 & 3.42 \\
\hline \multicolumn{2}{|c|}{ Mean } & 2.217 & 8.87 & 0.670 & 3.26 & 2.208 & 8.83 & 0.668 & 3.09 \\
\hline \multirow{4}{*}{$100 \%$} & 0 & 2.143 & 8.57 & 0.735 & 3.15 & 2.195 & 8.78 & 0.738 & 3.25 \\
\hline & 25 & 2.505 & 10.02 & 0.770 & 3.25 & 2.398 & 9.59 & 0.760 & 3.32 \\
\hline & 30 & 2.611 & 10.11 & 0.743 & 3.55 & 2.573 & 10.29 & 0.740 & 3.47 \\
\hline & 35 & 2.605 & 10.42 & 0.770 & 3.38 & 2.466 & 9.87 & 0.761 & 3.24 \\
\hline \multicolumn{2}{|c|}{ Mean } & 2.466 & 9.78 & 0.755 & 3.33 & 2.408 & 9.63 & 0.750 & 3.32 \\
\hline \multirow{4}{*}{$120 \%$} & 0 & 2.550 & 10.20 & 0.754 & 3.40 & 2.541 & 10.17 & 0.792 & 3.25 \\
\hline & 25 & 2.577 & 10.31 & 0.789 & 3.26 & 2.610 & 10.44 & 0.731 & 3.40 \\
\hline & 30 & 2.624 & 10.50 & 0.813 & 3.22 & 2.621 & 10.48 & 0.793 & 3.30 \\
\hline & 35 & 2.741 & 10.97 & 0.786 & 3.49 & 2.733 & 10.93 & 0.778 & 3.52 \\
\hline \multicolumn{2}{|c|}{ Mean } & 2.623 & 10.49 & 0.785 & 3.34 & 2.626 & 10.51 & 0.774 & 3.37 \\
\hline \multirow{4}{*}{ Averages } & 0 & 2.226 & 8.91 & 0.707 & 3.23 & 2.243 & 8.97 & 0.716 & 3.15 \\
\hline & 25 & 2.345 & 9.38 & 0.743 & 3.27 & 2.304 & 9.22 & 0.720 & 3.19 \\
\hline & 30 & 2.541 & 10.06 & 0.743 & 3.36 & 2.502 & 10.01 & 0.740 & 3.31 \\
\hline & 35 & 2.629 & 10.52 & 0.752 & 3.38 & 2.607 & 10.43 & 0.746 & 3.40 \\
\hline \multirow{3}{*}{$\begin{array}{c}\text { L.S.D. at } \\
5 \%\end{array}$} & Irrigation & 0.202 & 0.54 & 0.046 & N.S. & 0.064 & 0.26 & 0.038 & 0.28 \\
\hline & Compost & 0.157 & 0.56 & N.S. & N.S. & 0.129 & 0.52 & 0.033 & 0.28 \\
\hline & Interaction & 0.210 & 0.74 & N.S. & N.S. & 0.173 & 0.69 & 0.044 & N.S. \\
\hline
\end{tabular}

\section{Effect of compos levels:}

Data in Table (5) showed clearly that the addition of organic fertilizer which produced from recycling the agricultural residues (compost) caused an increase in total yield of fresh tubers of cassava and its some yield properties (average weight of tubers). Moreover, obtained data revealed that increasing the rate of organic compost up to 35 ton /fed. resulted in the highest total yield of tuber weights per plant $(2.623 \mathrm{~kg} /$ plant in the first season and 2.626 $\mathrm{kg} / \mathrm{plant}$ in the second season respectively). Also total yield of tuber per fed. recorded its highest weight (10.49 ton/fed. in the first season and 10.51 ton/fed. in the second season respectively). In other words, addition of 35 ton of organic compost fertilizer for each feddan had superiority in total tuber yield which amounted to $18.26 \%$ and $19.02 \%$ over control treatment (without compost addition) in the first and second seasons respectively. Regarding the average weight of tuber, the presented data Table (4) showed that their 
response to different rate of organic compost fertilizer was completely similar to the response of total tuber yield as previously mentioned. It might be concluded that addition of organic compost manure fertilizer to the cassava plants caused an increase of the nutritional elements in rooting zone consequently the more nutrients were absorbed, so more and enhancement of growth plant which caused an increase the tuber yield. Many investigators studied the behavior of many vegetable crops to the addition of organic fertilizer and obtained a data supported that mentioned here (Belay et al 2001, Amanullah et al 2006 and Makinde and Ayoola 2008).

\section{Effect of the interaction:}

Table (5) presented the effect of the interaction between water requirements with compost manure at three rates of the application in the two seasons. Whereas the highest yield of tubers of cassava which had the biggest average weight of tuber were associated with using $120 \%$ of water requirements with compost fertilizer at $35 \mathrm{ton} / \mathrm{fed}$. On the contrary, the lowest values of the previous criteria obtained when cassava plant were resaved $80 \%$ of water requirements and without compost fertilizer. These findings are in good accordance in both seasons.

\section{Physical and chemial tuber quality:}

Effect of irrigation water quantity:

Data in Table (6) showed that the lowest values of physical and chemical tuber quality were recorded with the plants which received low water level ( $80 \%$ of the calculated water requirements ). The highest values of physical and chemical tuber quality i. e. tuber length and diameter as well as N, Pand K were achieved when cassava plants were irrigated by $120 \%$ of the calculated water requirements. These results showed the same trend in both growing seasons. The high level of irrigation water (120\%) encouraged the vegetative growth of cassava plants as shown in Table (4) this in turn reflected its effect on tuber quality. These results are in agreement with those found by Olanrewaju et al (2009) and Obafemi et al (2011) they added that tuber quality of cassava was the best with continuos water supply. Data also cleared that there were significant differences between the tow levels $100 \%$ and $120 \%$ of water requirements.

\section{Effect of compos levels:}

The tabulated data Table (6) show that the cassava plants treated with defferent levels of compost manure indicated that, increasing the addition rate of compost manure up to $35 \mathrm{ton} / \mathrm{fed}$. caused an increment in physical tuber quality i. e. tuber lemgth and diameter and the all elemental nutrition values i.e. $\mathrm{N}, \mathrm{P}$, and $\mathrm{K}$ compared to the low rate addition. These results are completely similar in both two experimental seasons. Generally, it could abstracted that, the adding of highest rate of compost manure (35 ton/ fed.) gained the highest nutritional values, followed in descending order by the addition of compost manure at 30 ton/ fed., and finally, the application of 25 ton/fed. of compost manure. The highest rate of compost manure (35 ton/fed) caused more vigour plant growth, i.e., a strong rooting system consquently the uptakes of these elements were increased. Concerning to the superiority in the elemental values in tissues of cassava by increasing the compost manure rate, may be attributed to rich of this kind of fertilizer and 
when added at higher rate, the macro and micro elements are found in an enough quantity which required for a good plant growth, consequantly higher yield and more better tuber quality. The obtained results are in good agreement with that obtained by Belay et al 2001. Amanullah et al 2006 and Makinde and Ayoola 2008).

Table (6): Effect of water requirements and compost manure application on tuber quality of cassava plants average of two seasons.

\begin{tabular}{|c|c|c|c|c|c|c|c|}
\hline \multirow[b]{2}{*}{ Irrigation } & \multirow[b]{2}{*}{ Compost } & \multirow{2}{*}{$\begin{array}{c}\text { Tuber } \\
\text { length } \\
\text { cm }\end{array}$} & \multirow{2}{*}{$\begin{array}{c}\text { Tuber } \\
\text { diameter } \\
\mathbf{c m}\end{array}$} & \multicolumn{4}{|c|}{$\%$} \\
\hline & & & & $\mathbf{N}$ & $\mathbf{P}$ & $\mathbf{K}$ & $\begin{array}{c}\text { Carbohy } \\
\text { drate }\end{array}$ \\
\hline \multirow{4}{*}{$80 \%$} & 0 & 34.00 & 4.50 & 0.33 & 0.02 & 0.47 & 46.77 \\
\hline & 25 & 24.00 & 3.25 & 0.45 & 0.04 & 0.50 & 90.00 \\
\hline & 30 & 35.67 & 3.87 & 0.46 & 0.05 & 0.57 & 89.50 \\
\hline & 35 & 38.00 & 4.50 & 0.50 & 0.09 & 0.60 & 87.10 \\
\hline \multicolumn{2}{|c|}{ Mean } & 29.25 & 4.03 & 0.44 & 0.05 & 0.54 & 78.34 \\
\hline \multirow{4}{*}{$100 \%$} & 0 & 41.50 & 4.50 & 0.42 & 0.04 & 0.47 & 69.40 \\
\hline & 25 & 28.50 & 4.25 & 0.44 & 0.07 & 0.50 & 31.90 \\
\hline & 30 & 36.00 & 3.95 & 0.47 & 0.08 & 0.57 & 90.30 \\
\hline & 35 & 27.00 & 3.97 & 0.48 & 0.08 & 0.81 & 90.30 \\
\hline \multicolumn{2}{|c|}{ Mean } & 33.25 & 4.17 & 0.45 & 0.07 & 0.59 & 70.48 \\
\hline \multirow{4}{*}{$120 \%$} & 0 & 31.50 & 4.25 & 0.44 & 0.05 & 0.51 & 47.70 \\
\hline & 25 & 31.50 & 4.75 & 0.47 & 0.06 & 0.55 & 94.10 \\
\hline & 30 & 28.00 & 4.00 & 0.48 & 0.07 & 0.70 & 91.10 \\
\hline & 35 & 26.00 & 4.67 & 0.51 & 0.11 & 0.72 & 90.00 \\
\hline \multicolumn{2}{|c|}{ Mean } & 29.25 & 4.42 & 0.48 & 0.07 & 0.62 & 80.73 \\
\hline \multirow{4}{*}{ Averages } & 0 & 35.67 & 4.42 & 0.42 & 0.05 & 0.54 & 54.62 \\
\hline & 25 & 28.00 & 4.08 & 0.44 & 0.05 & 0.55 & 72.00 \\
\hline & 30 & 33.22 & 4.94 & 0.47 & 0.07 & 0.59 & 90.30 \\
\hline & \begin{tabular}{|c|}
35 \\
\end{tabular} & 30.33 & 4.38 & 0.49 & 0.08 & 0.64 & 89.13 \\
\hline \multirow{3}{*}{ L.S.D. at $5 \%$} & Irrigation & NS & NS & NS & NS & NS & NS \\
\hline & Compost & 6.00 & NS & NS & NS & NS & NS \\
\hline & Interaction & 8.01 & NS & NS & NS & NS & NS \\
\hline
\end{tabular}

\section{Effect of the interaction:}

In spite of the non-significant effect of the interaction of water requirements and compost manure at three rates of the application in the two seasonsTable (6), it could be concluded that, the highest values of bulb lemgth , diameter as well as $\mathrm{N}, \mathrm{P}$ and $\mathrm{K}$ in cassava bulb tissues were associated with that plants received higher water requirement $(120 \%$ of water requirement) and higher level of compost manure (35 ton/fed.). On the contrary, the lowest values from the above mentioned elements were obtained with adding cassava plant were resaved $80 \%$ of water requirements and without compost fertilizer. These findings are in good accordance in both seasons. 


\section{REFERENCES}

AbouEl-Magd, M.M.; Hoda,A. Mohammed and Z.F. Fawzy, 2005. relationships, growth and yield of broccoli with increasing N,P or K ratio in a mixture of NPK fertilizers. Annals Agri. Sci., Moshtohor, 43: 791805.

M. El-Bassiony and Z.F. Fawzy, 2006. effect of organic manure with or without chemical fertilizers on growth, yield and quality of some vatieties of Broccoli plants. J. Appli. Sci. Res., 2: 791798.

Alfredo A.C., A.A.C. Alves and L.S. Tim, 2000. Response of cassava to water deficit: Leaf area growth and abscisic acid. Crop Science, 40: 133-137.

Amanullah, M.M.; A. Alagesan; K. Vaiyapuri; S. Pazhanivelan and K. Sathyamoorthi, 2006. Intercropping and organic manures on the growth and yield of cassava. Res. J. Agri. Biol. Sci., 2: 183-189.

Ayoola, O.T. and B.A. Makinde, 2007. Complementary organic and inorganic fertilizer application: Intercrop growth and yield of Cassava, maze and melon intercrop with a relayed cowpea. Australian J. of Basic and Appli. Sci., 1 (3): 187- 192.

Ayuso, M.A.; J.A. Pascal; C. Garcia and T. Hermandez, 1996. Evaluation of urban wastes for Agri. Use. Soil Sci., Plant Nutrition, 42: 105-111.

Bayu, W.; N.F. Rethman; P.S. Hammers and G. Alemu, 2006. Effects of farmyard manure and inorganic fertilizers on sorghum growth, yield and nitrogen use in a semi-arid area of Ethiopia. J. Plant Nutrition, 29: $391-$ 407.

Belay, A.; A.S. Classens; F.C. Wehner and J.M. Beer, 2001. Influence of residual manure on selected nutrient elements and microbial composition of soil under long term crop rotation. South Afreca J; Plant Soil, 18:1-6.

Black, C.A., 1965. Methods of soil analysis, part 2 American Soci. Of Agronomy, INC., Publisher, Madison, Wisconsin, USA.

Brown, J.D. and Lilleland, 1958. Rapid determination of potassium and sodium in plant material and soil extracts by flamphotometery. Proc. Amer. Soc. Hort. Sci., 48: 341- 346.

Doormbos, J.S. and W.O. Pruitt 1977. Crop water reqoirements.Irrigation and Drainage Paper No. 24, FAO, Rome. Pp 144.

Dubais, M.; K.A Grilles; J.K. Kamilton; P.A. Rebers and F. Smith, 1951. Calorimetric methods for determination sugars and related substances. Analytical Chemistry, 28: 250-256.

El-Khatib, S.I.; A.A. Mansour and Sahar A Sherif 2007. Performance of cassava plant in sandy soil under different irrigation intervals, water quantities and plant spacing. J. Agri. Sci. Mansoura Univ., 32 (11): 9207-9220. 
El-Shakweer, M.H.; E.A. El-Sayed and M.S. Ewees, 1998. Soil and plant analysis as a guide for interpretation of the improvement effeciency of organic conditions added to different soil in Egypt. Communicat soil Sci. Plant Anal. 29: 2067- 2088.

Erdem, T.; E. Yesim; H. Orta and H. Okursoy, 2006. Water yield relationships of potato under different irrigation methods and regimens. Sci. Agric. Vol. 63 (3): 226-231.

FAO, 1996. Food balance sheets FAOSTAT database. FAO, Rome.

Fuglie K.O., 2002. Economic Prospects for Root and Tuber Crops for Starch and Animal Feed in Asia, Progress in Potato and Sweet Potato Research Indonesia, CIP - ESEA and IAARD, Indonesia.

Gomez, K.A. and A.A. Gomez (1984): Statistical procedures for Agriculture Research. Second Ed. Wiely Interscience Publ. John Willey and Sons, New York.

Ghuman, B.S., 2003. Mulch and irrigation effects on plant-water relations and performance of Cassava and sweet potato. International Institute of Trop. Agric. P.M.B.5320.

Hair, S.O. and Mary Lameberts 1995. Cassava production in Miami Dade county Florida, Tropical Res. And Eduction Center Univ. of Florida 18905 S.W, 280 street, Homestead.

Mabrouk A., M.A El-Sharkawy and H.C. James, 1987. Response of cassava to water stress. Plant and Soil, 100: 345-360.

Makinde, E.A. and O.T. Ayoola, 2008. Residual influence of early season crop fertilization and cropping system on growth and yield of Cassava. Americ. J. of Agric. And Biol. Sci., 3(4): 712- 715.

Obafemi, O.O.; A.A. Olufayo and P.G. Oguntude, 2011. water use growth and yield of drip irrigated cassava in a Humid Tropical Environment. Soil and Water Res., 6: 10-20.

Oguntunde P.G., 2005. Whole-plant water use and canopy conductance of cassava under limited available soil water and varying evaporative demand. Plant and Soil, 278: 371-383.

Olanrewaju, O.O.; A.A. Olufayo; P.G. Oguntunde and A.A. Llemobade, 2009. water use efficiency of manihot esculenta crantz under drip irrigation system in south western Nigeria. European J. of SCI. Res. 27 (4): 576-587.

Penman, H.L., 1948. Natural evaporation from open water, bare soil and grass proceedings. Royal Society of London, Series a, 193: 120-146.

Sharma, A.R. and B.N. Mittra, 1991. Effect of different rates of application of organic and nitrogen fertilizers in a rice-based cropping system. J. Agric. Sci.,117: 313- 318.

Singh, R. and R.B. Alderfer, 1966. Effect of soil moisture stress at different periods of growth of some vegetable crops. Soil Sci., 101: 69-80.

Singh, B.P., 1989. Irrigation water mangement for bush snap bean production. Hort. Sci., 24: 69-70.

Trough, E. and A.H. Meyer, 1939. Improvemenmt in denies colorimetric method for phosphorus and arsenic. Ind. Eng. Chem. Anal. Ed. 1:136139. 
Wiled, S.A.; R.B. Corey; J.G. Layer and K. Voigt, 1985. Soils and plant analysis for tree culture. Oxford and IBH Publishing Co. New Delhi.

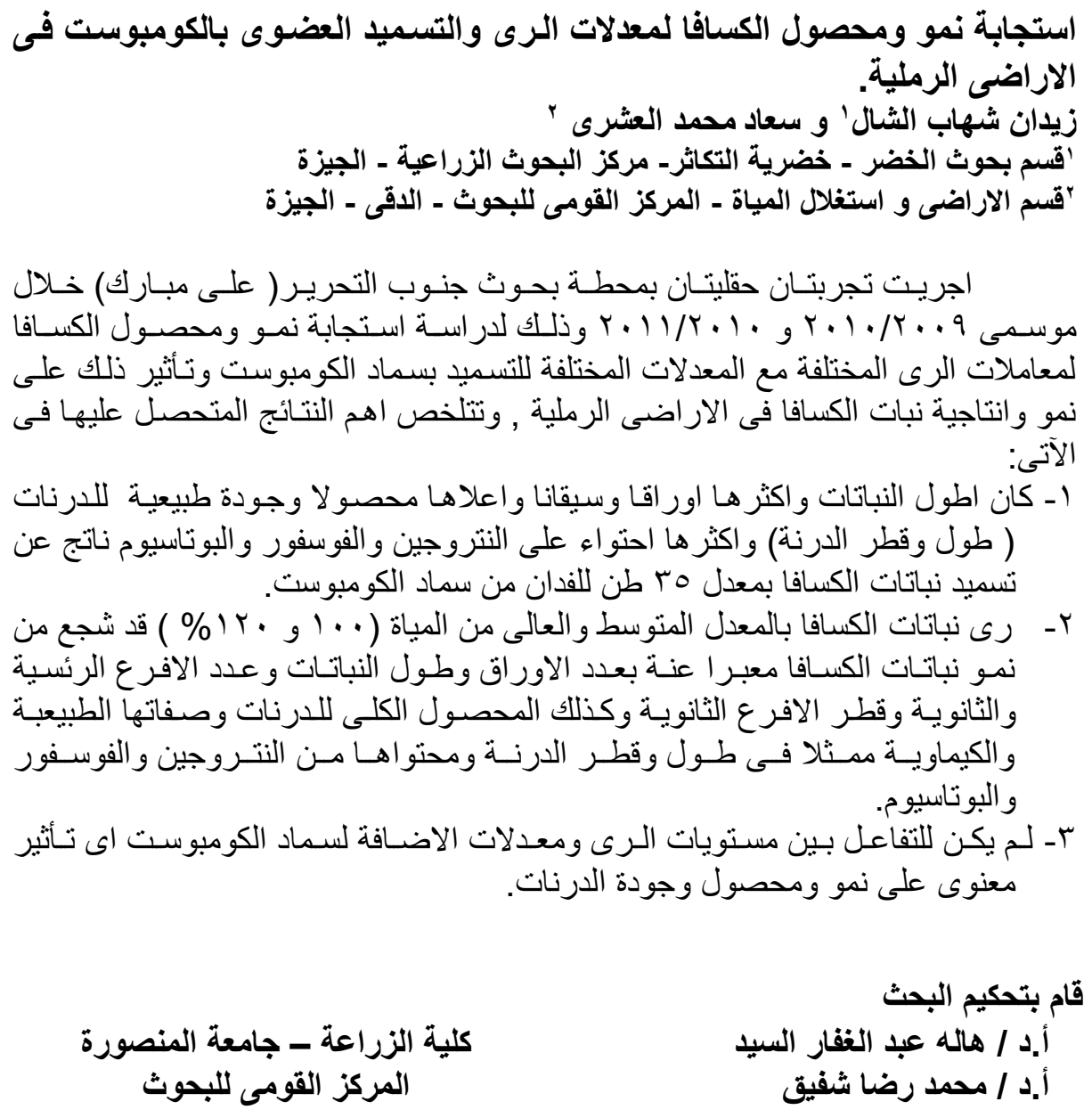

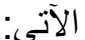

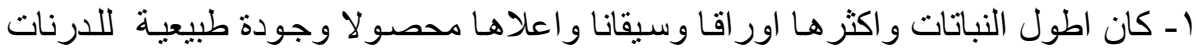

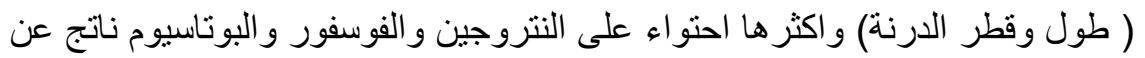

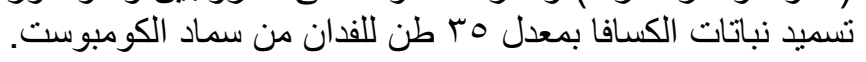

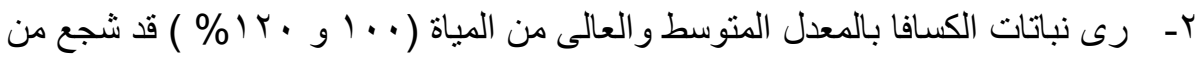

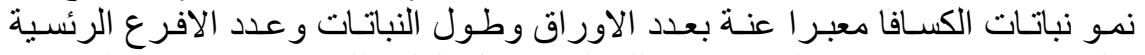

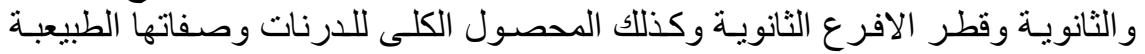

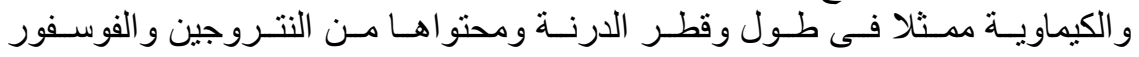

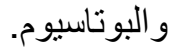

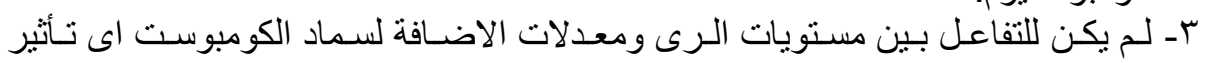
معنوى على نمو ومحصول وجودة الدرنات.

كلية الزراعة - جامعة المنصورة المركز القومى للبحوث

قام بتحكيم البحث إنه

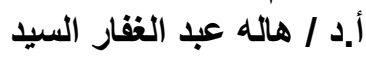

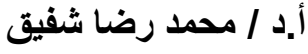


J. Plant Production, Mansoura Univ., Vol. 3 (7), July, 2012 
J. Plant Production, Mansoura Univ., Vol. 3 (7): 2211 - 2222, 2012

Table (4): Effect of water requirements and compost manure application on growth characters of cassava plants during two experimental seasons.

\begin{tabular}{|c|c|c|c|c|c|c|c|c|c|c|c|c|c|c|c|}
\hline \multirow{4}{*}{ Irrigation } & \multirow{3}{*}{ Compost } & \multirow{2}{*}{\multicolumn{2}{|c|}{ No. of }} & \multirow{3}{*}{$\begin{array}{c}\text { Stem } \\
\text { diameter }\end{array}$} & \multirow{3}{*}{$\begin{array}{l}\text { Plant } \\
\text { length }\end{array}$} & \multirow{3}{*}{\begin{tabular}{|c|} 
Stem \\
later \\
diameter
\end{tabular}} & \multirow{3}{*}{$\begin{array}{l}\text { No. of } \\
\text { later } \\
\text { stem }\end{array}$} & \multirow{3}{*}{\begin{tabular}{|c|} 
Diameter \\
of later \\
stem
\end{tabular}} & \multirow{2}{*}{\multicolumn{2}{|c|}{ No. of }} & \multirow{3}{*}{$\begin{array}{c}\text { Stem } \\
\text { diameter }\end{array}$} & & & & \\
\hline & & & & & & & & & & & & \multirow{2}{*}{$\begin{array}{l}\text { Plant } \\
\text { length }\end{array}$} & \multirow{2}{*}{$\begin{array}{c}\text { Stem } \\
\text { later } \\
\text { diameter }\end{array}$} & \multirow{2}{*}{$\begin{array}{l}\text { No. of } \\
\text { later } \\
\text { stem }\end{array}$} & \multirow{2}{*}{$\begin{array}{c}\text { Diameter } \\
\text { of later } \\
\text { stem }\end{array}$} \\
\hline & & aves & stems & & & & & & leaves & stems & & & & & \\
\hline & & \multicolumn{7}{|c|}{$2009 / 2010$} & \multicolumn{7}{|c|}{$2010 / 2011$} \\
\hline \multirow{4}{*}{$80 \%$} & 0 & 9.35 & 1.21 & 25.22 & 85.93 & 18.25 & 2.40 & 9.67 & 40.22 & 2.21 & 24.36 & 84.91 & 17.39 & 2.25 & 10.12 \\
\hline & 25 & & 1.58 & & & 18.26 & & & & & & & & & \\
\hline & 30 & & 1.88 & & & & & & & & & & & & \\
\hline & & & & & & & & & & & & & & & \\
\hline \multicolumn{2}{|c|}{ Mean } & & 1.68 & & & & & & & & & & & & \\
\hline \multirow{4}{*}{$100 \%$} & 0 & .77 & 1.33 & & & 18.39 & & & & 1.51 & & & & .73 & \\
\hline & & .76 & 2.15 & & & & & & & 2.09 & & & & & \\
\hline & & .85 & 2.35 & & & & & & & 2.2 & & & & & \\
\hline & & & 2.43 & & & & & & & 2.3 & & & & & \\
\hline \multicolumn{2}{|c|}{ Mean } & .03 & 2.07 & & 89 & 19.6 & 2.9 & & 48.05 & 2.03 & & & & 93 & \\
\hline \multirow{4}{*}{$120 \%$} & & .49 & 1.31 & & & 19.3 & & & 49.12 & 1.46 & & & 19.24 & 55 & \\
\hline & & & 1.93 & & & 20.20 & & & & 1.83 & & & 20.24 & 3.47 & \\
\hline & & & 2.15 & & & 20.44 & & & & 2.0 & & & & & \\
\hline & & & 2.11 & & & 686 & & & & 2.12 & & & & 46 & \\
\hline \multicolumn{2}{|c|}{ Mean } & 50.35 & 1.88 & & & 186.61 & & & 50.23 & 1.87 & & & 20.47 & 3.29 & \\
\hline \multirow{4}{*}{ Averages } & 0 & 44.54 & 1.29 & & & 18.66 & & & 44.85 & 1.73 & & 85.71 & 18.42 & 2.51 & .12 \\
\hline & 25 & 47.37 & 1.89 & & 86.83 & 19.26 & & & 47.04 & 2.02 & & 87.01 & 19.36 & 2.97 & .41 \\
\hline & 30 & 48.34 & 2.13 & 26.12 & 89.38 & 20.03 & 3.23 & & 48.00 & 2.08 & & 89.85 & 20.25 & 3.19 & .03 \\
\hline & 35 & 49.14 & 2.19 & 26.02 & 92. & 242.60 & & & 49.09 & 2.28 & 26.02 & 92.98 & 20.75 & 3.27 & 1.63 \\
\hline \multirow{3}{*}{$\begin{array}{c}\text { L.S.D. at } \\
5 \%\end{array}$} & igatio & 1.523 & 0.32 & & 1.3 & & 0.42 & & 1.58 & N.S. & & 0.16 & 0.28 & 0.54 & 0.45 \\
\hline & Compost & 1.594 & 0.41 & & 1.51 & N.S. & 0.37 & 0.37 & 0.94 & 0.43 & & 0.62 & 0.37 & 0.47 & 0.46 \\
\hline & Interaction & 2.127 & N.S. & N.S. & N.S. & N.S. & N.S. & 0.49 & 1.25 & N.S. & N.S. & 0.83 & 0.49 & N.S. & 0.62 \\
\hline
\end{tabular}


J. Plant Production, Mansoura Univ., Vol. 3 (7), July, 2012 


\section{El-Shal, Z. S. and Soad M. El-Ashry}

2226 